\title{
A fossil water measurer (Insecta, Hemiptera, Hydrometridae) from the Paleocene/Eocene of Denmark and its phylogenetic relationships
}

\author{
N. MØLLER ANDERSEN
}

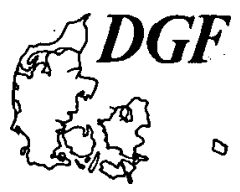

Andersen, N. Møller: A fossil water measurer (Insecta, Hemiptera, Hydrometridae) from the Paleocene/Eocene of Denmark and its phylogenetic relationships. Bull. geol. Soc. Denmark, vol. 30, pp. 91-96. Copenhagen, September 1st 1982. https://doi.org/10.37570/bgsd-1981-30-09

The first fossil species of hydrometrid bugs, Eocenometra danica n.gen., n.sp., is described from deposits of Upper Paleocene/Lower Eocene age (c. 50 million years) from northern Jutland, Denmark. The extinct form is compared with extant genera of the family Hydrometridae and its phylogenetic relationships are discussed. Paleoecological and biogeographical notes are included.

N. Møller Andersen, Zoological Museum, University of Copenhagen, Universitetsparken 15, 2100 Copenhagen Ø., Denmark, March 15th, 1982.

\section{Introduction}

Most members of the family Hydrometridae are extremely specialized insects inhabiting various freshwater localities. Particularly well known are the very elongate, almost needlelike bugs of the genus Hydrometra Latreille, also known as water measurers because of their usually slow and hesitating gait when they move about on the marginal vegetation and plant-covered water surface of ponds and quiet streams. No fossil representative of this group of semiaquatic bugs (Hemiptera-Heteroptera, infraorder Gerromorpha) has previously been described. During his visit to Denmark in 1976, Dr. Y. A. Popov, Moscow, brought to my attention a specimen of a hydrometrid bug among the rich material of fossil insects from the Upper Paleocene/Lower Eocene Mo Clay Formation (Hansen 1979) of northern Jutland, Denmark (collections of the Geological Museum, University of Copenhagen). This unique specimen is well enough preserved to permit the description of a new genus and species and comparisons with extant Hydrometridae.

\section{Eocenometra n.gen.}

Type-species: Eocenometra danica n.sp; by monotypy.
Diagnosis and description. Body very elongate. Head very slender, longer than thorax (as measured from anterior margin of prothorax to point of insertion of hind legs), but shorter than twice length of pronotum; head (in lateral view) swollen in basal and apical fourths (Fig. 5). Antennae very long, at least three times as long as head; first antennal segment relatively stout, almost two-thirds head length; second segment much shorter and more slender; third segment very long and threadlike. Rostrum slender, subequal in length to head. Pronotum almost two-thirds total length of thorax (measured as above), slightly arched above in lateral view. Points of insertion of legs on thorax almost equally spaced longitudinally. Legs slender and very long (Fig. 3), hind leg about 1.6 times total length of insect; fore femur distinctly shorter than middle femur, latter slightly shorter than hind femur; tibia of each leg longer than femur; tarsi short and very slender with small, apical claws (Fig. 7). Abdomen (as measured from the point of insertion of hind leg to apex) about two-thirds body length (excl. head). Hind corner of connexivum pointed. Genital segments of female small but distinct (Fig. 8).

Comparative notes. The elongate body, extremely prolonged head, and very long and slender appendages identify this fossil form with bugs 

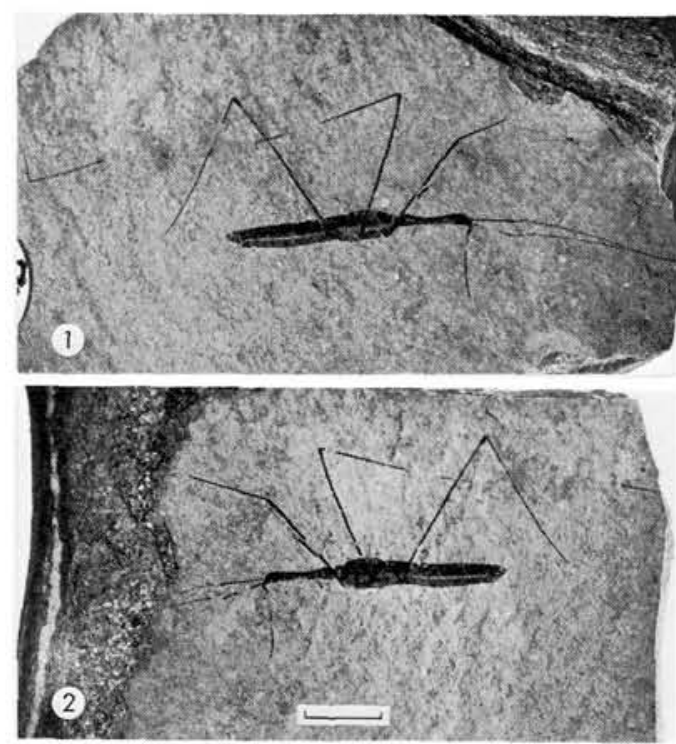

Figs 1-2. Eocenometra danica n.gen., n.sp. Holotype. Cementstone, Mo Clay Formation (Upper Paleocene/Lower Eocene), Mors, northern Jutland, Denmark. Fig. 1. MGUH 15912A. Fig. 2. MGUH 15912B. Scale $5 \mathrm{~mm}$.

of the family Hydrometridae, subfamily Hydrometrinae. Eocenometra n.gen. shares with the genus Bacillometra Esaki the relatively short and robust thorax (compare Figs. 9 and 10) and the equidistant insertion of the three pair of legs. Both genera differ in these characters from $\mathrm{Hy}$ drometra (Fig. 11). The relatively long first antennal segment separates the fossil genus and species from species of Bacillometra and Hydrometra, which all have antennae where the first segment is much shorter than the second. In the two aberrant hydrometrine genera Dolichocephalometra Hungerford and Chaetometra Hungerford (described under the preoccupied name Trichometra Hungerford), the two basal antennal segments are subequal in length, but the first segment is in both genera distinctly shorter (i.e., in relation to head and thorax) than in the fossil genus.

\section{Eocenometra danica n.sp.}

Material examined: Holotype, probably a female, in cementstone from Upper Paleocene/Lower Eocene Mo Clay Formation, Vester Sundby,
Mors, Denmark, labelled 1975, 922A and 922B (plate and counterplate), collector M. Sørensen. Holotype deposited in the Geological Museum, University of Copenhagen (Nos. MGUH 15912A \& B).

Description. The single specimen (probably a female) is fairly well preserved in both plate and counterplate (Figs. 1-2), which make it possible to give an almost complete reconstruction of the body and its appendages (Fig. 3). The insect has been impressed in a lateral position (or almost exactly so) which, however, excludes any description and measurements taken from a dorsal or ventral position. The total length (from apex of head to apex of abdomen) is $15.8 \mathrm{~mm}$. The species is thus relatively large for a hydrometrid, and matches the size of the largest living species of Hydrometra. The dorsal and ventral outlines of the head are fairly distinct (Fig. 5), but the eyes could not be located and the ratio between the ante- and postocular parts of head is therefore unknown; the total length of the head is $5.0 \mathrm{~mm}$. The swollen, anterior region of head shows the protruding anteclypeus (Fig. 5, AC) and semicircular ventral lobes of head (VL), which probably conceal the basal labial segments. Traces of pubescence are visible in some parts of the head (Fig. 6); the pubescence consists of slender setae and a few hook-shaped hairs; the latter are characteristic elements of the macrohair layers of Hydrometra (Andersen, 1977b). The antennae (Fig. 3, a) are inserted close to the apex of head; the second and especially the first segment are much stouter than the third segment and are covered by numerous fine hairs (Fig. 4); lengths of antennal segments 1-3 (perhaps incomplete; segment 4 probably missing): $3.1,1.0$, and 10 mm. Rostrum (Fig. 3, r) $4.8 \mathrm{~mm}$ long, slightly swollen at base, tapering to pointed apex; third labial segment (Fig. 5, La3) very long, perhaps more than six times fourth segment (La4). Thorax length (from anterior margin of prothorax to point of insertion of hind legs) $4.1 \mathrm{~mm}$; length of pronotum $2.8 \mathrm{~mm}$. Distances between points of insertion of fore and middle legs $2.0 \mathrm{~mm}$, and of middle and hind legs $1.9 \mathrm{~mm}$. Leg femora of right side almost intact: fore femur $7.5 \mathrm{~mm}$, middle femur $9.3 \mathrm{~mm}$, and hind femur $11 \mathrm{~mm}$; tibiae incomplete, and only approximate lengths can be given: fore tibia $9 \mathrm{~mm}$, middle tibia $10 \mathrm{~mm}$, and hind tibia $13 \mathrm{~mm}$; fore and middle tarsi (Fig. 3, f 

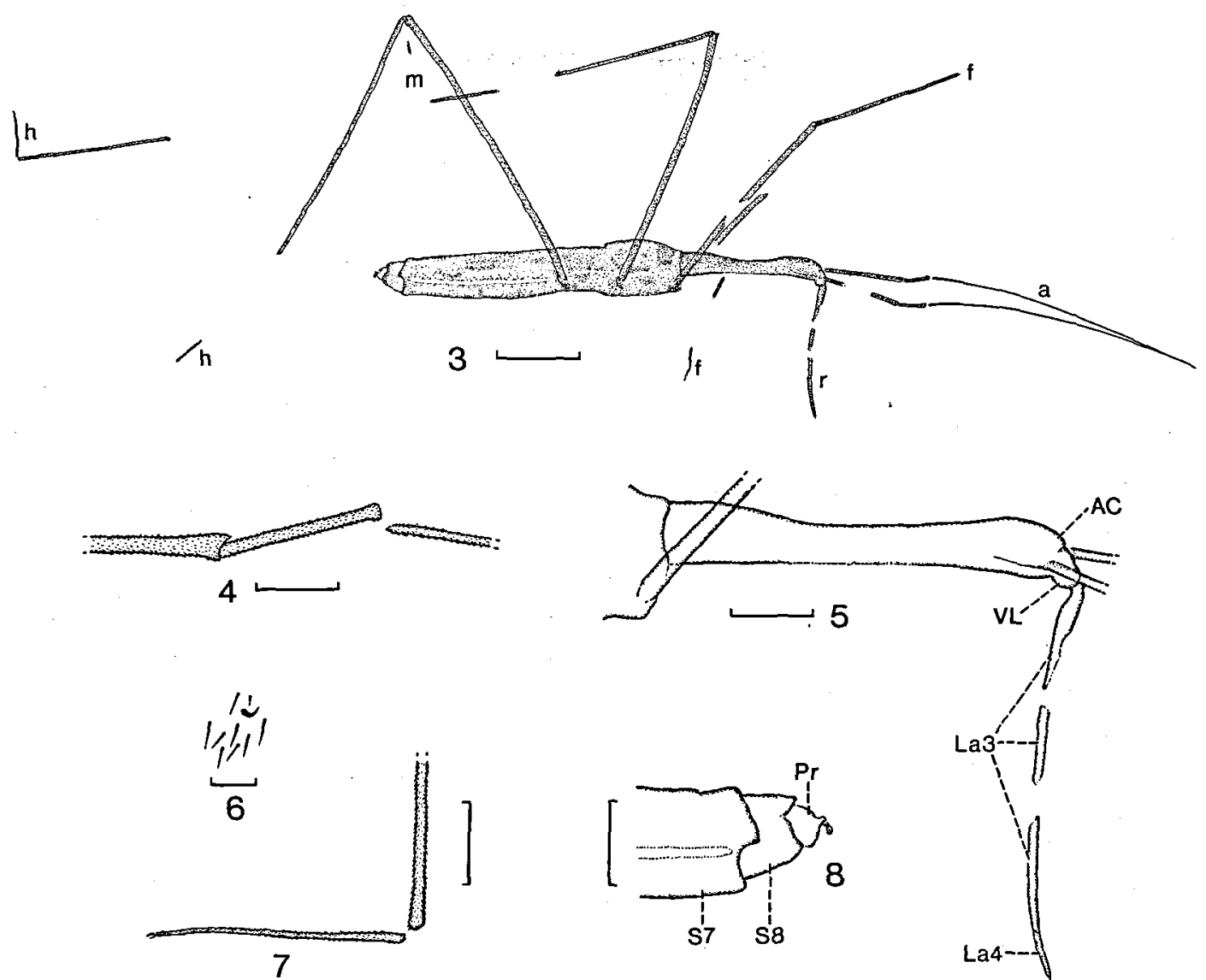

5

Figs. 3-8. Eocenometra danica n.gen., n.sp. Fig. 3 Specimen reconstructed from plate and counterplate (Figs 1-2); a, antennae; r, rostrum; f, m, h, fore, middle, and hind legs. Scale $5 \mathrm{~mm}$. Fig. 4 . Antennal segments 1 (apex), 2, and 3 (base). Scale $0.5 \mathrm{~mm}$. Fig. 5 . Outline of head (except antennae); AC, anteclypeus; La3, La4, labial segments 3 and 4; VL, ventral lobe of head. Scale $1 \mathrm{~mm}$. Fig. 6. Detail of hair layer of head. Scale $0.02 \mathrm{~mm}$. Fig. 7. Hind tibia (apex) and tarsus. Scale $0.5 \mathrm{~mm}$. Fig. 8. Abdominal end; Pr, proctiger; S7, S8, abdominal segment 7 and 8 . Scale $0.5 \mathrm{~mm}$.

and $\mathrm{m}$ ) incomplete, but perhaps 1 and $2 \mathrm{~mm}$, respectively; hind tarsus (Fig. 3, h) intact, measuring $1.7 \mathrm{~mm}$, very slender, tapering from base to apex (Fig. 7); segments of tarsus (probably three in number) not discernible; claws very small. Leg segments covered with a pubescence of fine hairs. No traces of wings although the specimen probably was macropterous (pronotum distinctly arched). Abdomen rather high in the specimen at hand but this is most likely the result of compression; total length of abdomen (from the point of insertion of hind legs to the apex) 6.7 $\mathrm{mm}$; a median, unpigmented, longitudinal band in the abdomen may indicate the connexival margin; intersegmental sutures of abdomen invisible except for one (probably between sternum 2 and
3). Apex of abdomen (Fig. 8) showing hind margin of segment 7 (S7) with distinctly pointed connexival corner, segment 8 (S8), and proctiger (Pr); the genital segments are probably protracted in the specimen at hand.

Geological horizon: Mo Clay Formation (probably the upper insect layer of Larsson 1975, ash layer nos. 25-30), Upper Paleocene/Lower Eocene, c. 50 million years before present (see Hansen 1979).

Type-locality and distribution: Mors, northern Jutland, Denmark. 


\section{Phylogeny}

Fossil insects (especially those contained in rocks) are rarely well enough preserved to permit an accurate identification and evaluation of relationships with living insects. However, the fossil bug described above is preserved in such a fine state that no doubt is left about it belonging to the heteropterous family Hydrometridae. This family is, above all, characterized by the prolonged state of the head capsule and, in the most advanced forms, by the very elongate body and slender, almost threadlike appendages. The phylogeny of the seven extant genera of the Hydrometridae was discussed earlier by me (Andersen 1977a) and a cladogram of relationships presented. The degree of structural modification of most body parts increases from Veliometra Andersen (which resembles members of the Macroveliidae, the sister-group of the Hydrometridae; Andersen 1979) to the genera of the subfamily Hydrometrinae. Species of the latter group have extremely prolonged head and body and very slender appendages, characters also shared by Eocenometra danica n.gen., n.sp. Although it is impossible to tell whether the fossil species had other of the autapomorphic characters of the subfamily $\mathrm{Hy}-$ drometrinae, e.g., absence of a metathoracic scent apparatus, it is fairly safe to classify Eocenometra in this subfamily. Its relationships with the four extant hydrometrine genera are more uncertain. The head is not as long relative to the body as in Dolichocephalometra, Chaetometra,
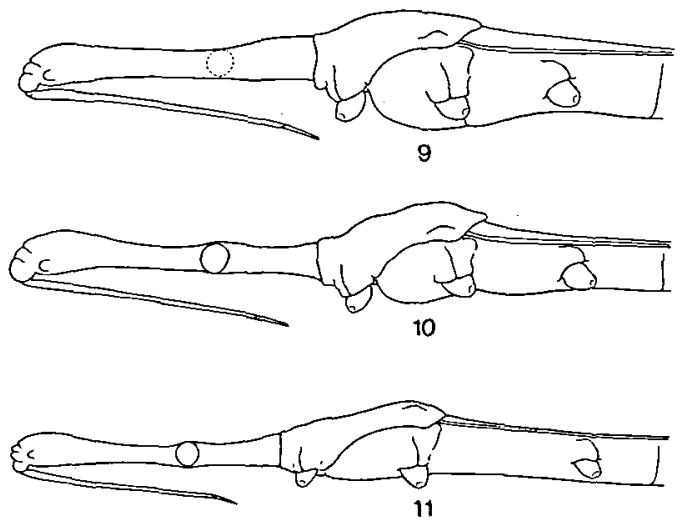

Figs. 9-11. Head, thorax, and basal abdomen in lateral view. Not drawn to the same scale. Fig. 9. Eocenometra danica n.gen., n.sp., (reconstruction). Fig. 10. Bacillometra fuallagana Drake. Fig. 11. Hydrometra sp.

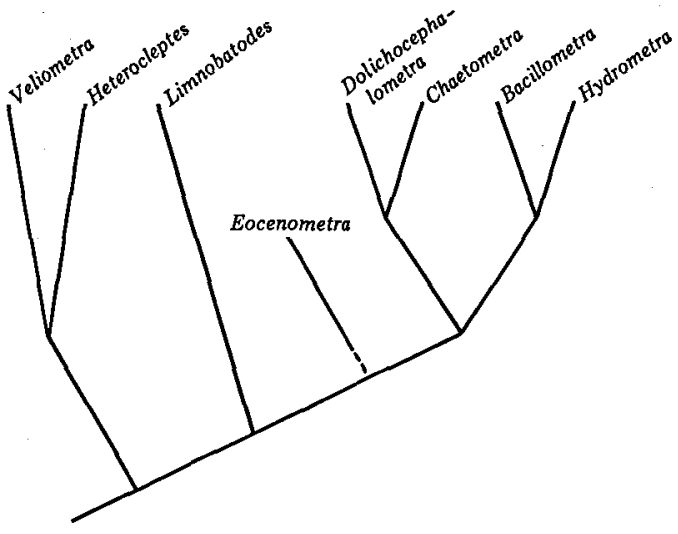

Fig. 12. Cladogram of relationships between extant genera of Hydrometridae with tentative positon of the extinct Eocenometra.

Bacillometra, and some Hydrometra spp. On the other hand, the structure of the thorax is more like that of the first three genera, i.e., the metathorax is not prolonged as in Hydrometra (Figs. 9-11). It is significant, however, that the first antennal segment of Eocenometra is much longer than the second, while it is subequal to or distinctly shorter than the second segment in the four hydrometrine genera. The antennal structure of Eocenometra is probably the most plesiomorphic of the subfamily and is shared with the non-hydrometrine members of the family. On this basis, Eocenometra could be placed as the sister-group of the four extant genera of Hydrometrinae (Fig. 12).

Several species of semiaquatic bugs (Gerromorpha) have been described or recorded from Tertiary deposits. Scudder (1890) described new genera and species of both Veliidae and Gerridae ( $=$ Hydrobatidae) from the Oligocene/Miocene of North America, but their relationships and taxonomic status cannot be settled from the original descriptions and illustrations. A number of fossil "Gerris" species have been described from geological deposits of similar ages in Europe and North America. The Upper Paleocene/Lower Eocene Mo Clay from Denmark which contained Eocenometra danica n.gen., n.sp., is very rich in insect fossils. Among these are no less than 12 specimens of Gerridae (personal observations). These belong to the Geological Museum, University of Copenhagen, and the Museum of the island Fur, northern Jutland. Habitually, 
these gerrids resemble modern species of Gerris and their allies (see Andersen in press: Plate 15, $A$ and $B$ ). One species is very large, measuring about $32 \mathrm{~mm}$, thus matching in size the largest living water strider, Gigantometra gigas (China) from Indochina. Although these fossils are well preserved, their generic relationships with extant forms cannot be determined with any accuracy.

Fossilized resin or amber, famous for its containments of extremely well-preserved insects, has also provided specimens of semiaquatic bugs. According to Bachofen-Echt (1949: 172; here from Larsson 1978: 119), three species of Gerridae are known from Baltic amber (probably of Eocene age). The Danish amber collection (Zoological Museum, University of Copenhagen) includes two gerrid nymphs (see Larsson 1978: Plate 8, A) and the head and thorax of one adult specimen of Veliidae (see Andersen in press: Fig. 510 ), habitually similar to living species of the genera Velia and Paravelia. Finally, one species of the family Hebridae has been found in Oligocene amber from Mexico (Chiapas); it resembles a modern Hebrus sp. (J. T. Polhemus in litt.).

The fossil record of Tertiary gerromorphans only allows the conclusion that the families Hebridae, Hydrometridae, Veliidae, and Gerridae already were represented by species typical of their respective groups during the Upper Paleocene-Oligocene Period. Based on other kinds of evidence, e.g., inferences about the historical biogeography of the groups, it is suggested that the origins of the families of Gerromorpha date further back in the geological history, probably to the beginning of the Mesozoic Era (Andersen in press). The identification by Popov and Wootton (1977) of a fossil bug from the Lower Jurassic of Germany as belonging to the Gerromorpha must, however, be viewed with great reservation. So far the Danish Upper Paleocene/Lower Eocene fossils appear to be the oldest safely identified gerromorphans.

\section{Paleoecology}

The Mo Clay Formation in northern Jutland (exposed in several places in the western Limfjord area, e.g., on the islands Mors and Fur) comprises a highly porous diatomite, socalled Mo Clay, which mainly consists of diatomaceous shells and a small clay content. The formation also contains numerous layers of volcanic ash and a few horizons with calcareous cementstone. The Mo Clay Formation is rich in fossil vertebrates, especially pelagic fishes (Bonde 1979), and contains a poor marine invertebarte fauna, but many terrestrial plant remains. In a few of the horizons with cementstones there are strikingly many remnants of insects (Larsson 1975). Since the Mo Clay is a marine deposit, the insects must have been transported for quite some distance, possibly airborne, before they settled on the bottom of the sea. Bonde $(1973,1979)$ assumed the deposition of the Mo Clay in a distance of about $100 \mathrm{~km}$ from the nearest coast (southwestern part of a Scandinavian landmass) and at a water depth of a few hundred meters. The composition of the fish fauna indicates a relatively higher water temperature than at present, probably a subtropical climate (Bonde 1979, see also Buchardt 1978).

From the composition of the insect faunas of the Mo Clay, Larsson (1975) estimated that the insects were derived from one or more areas dominated by meadows with shrubby vegetation, but lacking true forests. Judging by the numbers of insects connected with water, including one species of true water bugs of the family Belostomatidae (see Larsson 1975: Fig. 5), these areas must also have been rich in bodies of stagnant or slowly flowing freshwater.

Eocenometra danica n.gen., n.sp., is habitually very similar to living species of the genus Bacillometra. These hydrometrids are inhabitants of streams, living under overhanging banks close to the water's edge but able to move on the water surface with great agility (Hungerford 1935). The relatively stout thorax and long legs of Eocenometra suggests a similar ability to skate on the water.

\section{Biogeography}

The family Hydrometridae has an almost worldwide distribution in the Recent fauna. The genus Hydrometra (with c. 100 species) is cosmopolitan, Bacillometra (4 species), Limnobatodes Hussey, and Veliometra (both monotypic) are restricted to Middle and South America, whereas the known distribution of Heterocleptes Villiers 
(4 species) includes West and Central-Africa, and Borneo (Andersen 1982); finally, the monotypic genera Dolichocephalometra and Chaetometra are both endemic to the Marquesas Islands in the eastern Pacific. The distributional pattern of the extant genera suggest a hypothesis of primitive cosmopolitanism for the family Hydrometridae (Andersen 1977a, in press). The discovery of the primitive hydrometrine Eocenometra danica n.gen., n.sp. in the Upper Paleocene/Lower Eocene of Denmark suggests that this hypothesis also applies to the subfamily Hydrometrinae.

Acknowledgements. I am indebted to Dr. Y. A. Popov, Palaeontological Institute, Moscow, for bringing the fossil hydrometrid to my attention, and to Drs Niels Bonde and Soren Floris, Geological Institute and Museum, University of Copenhagen, for critical comments and for the opportunity to study this interesting specimen, respectively. Mr. G. Brovad, Zoological Museum, University of Copenhagen, has taken the photographs and Dr. Mary E. Petersen has corrected the English text. This paper is part of a project supported by grants from the Danish Natural Science Research Council.

\section{Dansk sammendrag}

Den første fossile art tilhørende tægefamilien Hydrometridae, Eocenometra danica n.gen., n.sp., beskrives fra det Øvre Paleocæne/Nedre Eocæene Móler (ca. 50 millioner år gammelt) fra Nordjylland (Mors). Efter sammenligning med de nulevende slægter af familien Hydrometridae, diskuteres den fossile forms fylogenetiske slægtskabsforhold og palæoøkologiske sammenhæng, samt den biogeografiske betydning af fundet.

\section{References}

Andersen, N. Møller 1977a: A new and primitive genus and species of Hydrometridae (Hemiptera, Gerromorpha) with a cladistic analysis of relationships within the family. Ent. scand. 8: 301-316.

Andersen, N. Møller 1977b: Fine structure of the body hair layers and morphology of the spiracles of semiaquatic bugs (Insecta, Hemiptera, Gerromorpha) in relation to life on the water surface. Vidensk. Meddr dansk naturh. Foren. 140: 7-37.

Andersen, N. Moller 1979: Phylogenetic inference as applied to the study of evolutionary diversification of semiaquatic bugs (Hemiptera: Gerromorpha). Syst. Zool. 28: 554-578.

Andersen, N. Møller 1982: The first species of Heterocleptes Villiers from the Oriental region (Hemiptera, Hydrometridae). Ent. scand. 13: 105-108.

Andersen, N. Møller in press: The Semiaquatic Bugs (Hemiptera, Gerromorpha). Phylogeny, adaptations, biogeography and classification. Entomonograph 3.

Bachofen-Echt, A. v. 1949: Der Bernstein und seine Einschlüsse. Wien. 204 pp.

Bonde, N. 1973: Fiskefossiler, diatomiter og vulkanske askelag. Dansk geol. Foren., Arsskr. f. 1972: 136-143.

Bonde, N. 1979: Palaeoenvironment in the 'North Sea' as indicated by the fish bearing Mo-clay deposit (Paleocene/ Eocene), Denmark. Meded. Werkgr. Tert. Kwart. Geol. 16: 3-16.

Buchardt, B. 1978: Oxygene isotope palaeotemperatures from the Tertiary period in the North Sea area. Nature: 121-123.

Hansen, J. M. 1979: Age of the Mo-Clay Formation, Bull. geol. Soc. Denmark 27: 89-91.

Hungerford, H. B. 1935: The genus Bacillometra Esaki, including the description of a new species from Peru (Hemiptera, Hydrometridae). Rev. de Entomol 5: 117-123.

Larsson, S. G. 1975: Palaeobiology and mode of burial of the insects of the Lower Eocene Mo-clay of Denmark. Bull. geol. Soc. Denmark 24: 193-209.

Larsson, S. G. 1978: Baltic Amber - A Palaeobiological Study. Entomonograph 1: 1-192.

Popov, Y. A. \& Wootton, R. J. 1977: The Upper Liassic Heteroptera of Mecklenburg and Saxony. Syst. Ent. 2: 333-351.

Scudder, S. H. 1890: The Tertiary insects of North America. Report of the U.S. Geological Survey of the Territories 13: 1-734. 